\title{
SS-069 マインドワンダリング！一ぼんやりする心の科学
}

\author{
企画代表者, 話題提供者：関口 貴裕 (東京学芸大学) \\ 企画者, 司会者: 森田 泰介 (東京理科大学) \\ 話題提供者：井関 龍太 (理化学研究所) \\ 話題提供者: 梶村 昇吾 (京都大学) \\ 話題提供者:松本＼cjkstart昇 (筑波大学 /日本学術振興会) \\ 指定討論者：篠原 一光 (大阪大学) \\ 指定討論者：及川恵 (東京学芸大学)
}

眼前の課題とは無関係な内的な思考に注意が向く現象はマインドワンダリング（MW）と呼ばれる。 MW は我々の心的活動において本質的な地位を占めるものであると考えられることから近年国内外で関 心が高まってきている。本シンポジウムでは MW に関する基礎的研究の成果を持ち寄り「ぼんやりする 心の科学」の最先端について活発な知的交流を行う場を展開したい。具体的には, MW 研究の全体像を 概観した後， MW と注意制御との関わりの探索，非侵襲脳刺激法による MW の脳神経基盤の解明，自 伝的記憶検索に及ぼす MW の影響の研究の成果について気鋭の研究者達が話題提供を行う。その上で, 応用心理学・臨床心理学の立場から, 現在の MW 研究の問題点や今後期待されることについて厳しい指 摘・注文を受ける。MW の本質や意味, 方法論上の問題点等, 今後の $\mathrm{MW}$ 研究の健全な発展のために 今確認すべきことについて，フロアの方々とともに議論を深めることができれば幸甚である。

第2 日 9 月23日 (水) $15: 30 \sim 17: 30$

第16会場 $/ 2$ 号館 231

\section{SS-070 宗教性／スピリチュアリティと精神的健康の関連（3）一科研 費研究プロジェクトの 3 年間の活動で見えてきたもの一}

\author{
企画代表者, 話題提供者：中尾 将大 (大阪大谷大学) \\ 企画者, 司会者：松島 公望（東京大学） \\ 話題提供者：川島 大輔 (中京大学) \\ 話題提供者：大村 哲夫 (東北大学) \\ 話題提供者：具志堅伸隆 (東亜大学) \\ 話題提供者：酒井 克也 (出雲大社和貴講社) \\ 指定討論者: 荒川＼cjkstart歩（武蔵野美術大学）
}

2012年度より科研費研究プロジェクト（宗教性／スピリチュアリティと精神的健康の関連一苦難への 対処に関する実証的研究一, 課題番号24330185）を立ち上げ，この問題について取り組み， 3 年間の活 動を行った。本研究プロジェクトでは，日本に㧍ける宗教性／スピリチュアリティと精神的健康との関 連について実証的に検討することを目的とした。その目的を達成するために, 質的研究班, 数量的研究

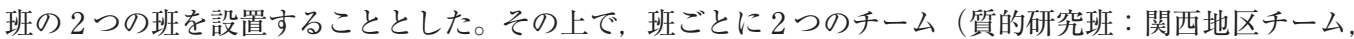
東北地区チーム, 数量的研究班: 浄土真宗チーム，5つの宗教教団と一般日本人チーム）を設置し，そ れぞれのチームごとに調查研究を行った。本シンポジウムでは, 研究プロジェクトに抒ける研究成果を 報告する。それらの報告を基に，日本における宗教性／スピリチュアリティと精神的健康の関連の意義 や可能性について検討したいと考えている。 